\title{
Pengantar Redaksi:
}

\section{Menelisik Konsep, Lembaga dan Pengorganisasian Tatanan Sosial di Indonesia}

Jurnal Pemikiran Sosiologi Volume 7 Nomor 1, Januari - Juli 2020 menghadirkan penerbitan yang bertema Menelisik Konsep, Lembaga dan Pengorganisasian Tatanan Sosial di Indonesia. Penerbitan edisi pertama Volume 7 kali ini merupakan upaya untuk mengidentifikasikan kembali tema mengenai tatanan sosial yang secara klasik menjadi pembahasan utama dalam Sosiologi khususnya dalam perspektif yang mengutamakan konstruksi sosial sebagai suatu bentuk kontrak atau perjanjian, kesepakatan-kesepakatan yang dilakukan oleh segala unit masyarakat, mulai dari unit terkecil yakni keluarga hingga unit terbesar dalam masyarakat yakni instusi dan atau kelembagaan (baik yang bersifat sosial, kultural, ekonomi maupun politik). Upaya menelisik tradisi klasik tentang 'tantanan sosial sebagai suatu bentuk kontrak sosial' dalam Sosiologi dilakukan sebagai suatu usaha untuk mengidentifikasi tema kajian sosial humaniora tentang tatanan sosial yang selalu berkembang, sementara itu gagasan atau teori-teori mengenai tatanan sosial terutama yang berbasis pada teori Fungsionalisme sepertinya perlu dikaji ulang. Hal ini berkenaan dengan perubahan sosial yang melingkupi segala aspek relasi sosial, mulai dari relasi yang bersifat privat hingga relasi yang bersifat publik, baik yang bersifat sakral maupun bersifat provan.

Menurut Michael Hechter dan Christine Home (2003), dalam buku 'Theories of Social Order" setidaknya terdapat tujuh tema sentral dalam kajian mengenai 'tatanan sosial' (social order) di dalam konteks masyarakat moderen tingkat lanjut dimana perubahan sosial terjadi secara pesat melalui globalisasi. Ketujuh tema sentral tersebut adalah; (1) Kelompok, Jaringan dan Masyarakat Jejaring; (2) Status Sosial; (3) Nilai dan Norma; (4) Kekuasaan dan Otoritas; (5) Tatanan yang bersifat Spontan (sementara); (6) Penghargaan atau Pencapaian (attainments); (7) Kehornatan Sosial (social honor). Pembahasan Hecter dan Home (2003) merupakan suatu upaya epistemologis untuk memperbaharui kajian sosiologis tentang tatanan sosial dengan memetakan ulang gagasan-gagasan pemikiran 'klasik' dalam teori-teori Sosiologi dan kelanjutannya oleh para pemikir teori-teori Sosiologi moderen. Secara epistemologis, kajian tatanan sosial berakar dari pemikiran Thomas Hobes tentang "kontrak sosial'. Para pemikir "Sosiologi Klasik" seperti Durkheim, Marx dan Weber juga mengembangkan perhatian mereka tentang tema ini. Durkheim menganggap tatanan sosial berakar dari "nilai dan norma" yang berkembang di dalam suatu masyarakat. Marx, menilai bahwa tatanan sosial berkembang dalam sejarah material peradaban manusia. Oleh karena itulah, menurutnya tatanan sosial harus dilihat sebagai suatu "hubungan" (relasi) sosial dalam konteks produksi dan reproduksi perkembangan kapitalisme. Sementara Weber melihat tatanan sosial sebagai kombinasi antara pelembagaan norma dan nilai sosial yang berdampak pada relasi kuasa dan otoritas hingga status sosial. Para pemikir Sosiologi moderen seperti Talcott Parsons, Jurgen Habermas, dan Pierre Bourdieu menekankan pentingnya mengkaji tatanan sosial dan perubahan sosial dalam masyarakat kapitalis tingkat lanjut. Menurut Parsons, tatanan sosial merupakan seperangkat institusi sosial yang mengatur pola-pola tindakan dan fungsi sosial yang dipengaruhi oleh nilai dan norma kultural. Sementara menurut Jurgen Habermas, tatanan sosial melampaui sekedar instusi atau pelembagaan norma sosial, melainkan juga meliputi suatu "tindakan komunikatif" dimana komunikasi dan kerjasama dilakukan berdasarkan kompromi dan kesepakatan-kesepakatan antar individu di dalam masyarakat sehingga mengembangkan pola jejaring dalam pelembagaannya. Pierre Bourdieu adalah seorang pemikir Sosiologi Moderen yang paling tekun mengembangkan minat dan kajian mengenai 'tatanan sosial' dan perubahannya dalam konteks masyarakat kapitalis tingkat lanjut. Bourdieu secara epistemologis mengkombinasikan teori kritis dalam tradisi Marxian tentang hubungan produksi dan tradisi Weberian tentang sistem simbolik dan pelembagaannya dalam kehidupan sosial, misalnya melalui gagasannya tentang "ranah" (field) sebagai pintu masuk (entry point) untuk mengkaji tema-tema sentral tentang tatanan sosial. 
Berkenaan dengan publikasi tema sentral mengenai “Tatanan Sosial” dalam edisi kali, JPS Vol 7 (1) telah memilih enam artikel yang dapat mewakili identifikasi terkini atas gagasan, pelembagaan dan pengorganisasian tatanan sosial di Indonesia. Keenam artikel tersebut secara tematik mewakili bagaimana tatanan sosial berlangsung dalam ranah privat hingga ranah publik dan menjadi subyek kajian yang bersifat dinamis. Artinya, kajian yang disampaikan tersebut didasari oleh temuan-temuan faktual di lapangan dan karenanya perubahan yang berlangsung masih bersifat dinamis (cair) dan tidak sepenuhnya menetap. Artikel pertama disajikan oleh Sony Setiawan yang berjudul "Implementasi POLMAS dalam Pencegahan Tawuran: Studi Kasus POLRES Metro Bekasi". Artikel ini membahas implementasi Polmas atau Pemolisian masyarakat (community policing) yang dilakukan anggota Bhabinkamtibmas Polres Metro Bekasi Kota sebagai upaya deteksi dini tawuran. Gagasan tentang pemolisian masyarakat (community policing) dalam hemat redaksi Jurnal Pemikiran Sosiologi memang merupakan tema yang problematis, meski demikian artikel yang diajukan ini membahas bagaimana gagasan community policing secara ideal menjadi tantangan tersendiri bagi kepolisian. Artikel kedua disajikan oleh Mutiya Noorfiana dan Sulismadi tentang "Dampak Akselerasi CSR PT Semen Indonesia (Persero) Tbk pada Petani Greenbelt di Tuban." Artikel ini mendeskripsikan dampak akselerasi program Corporate Social Responsibility (CSR) PT Semen Indonesia (Pesero) Tbk bagi petani greenbelt di Tuban yang dilatarbelakangi oleh keunikan dari program greenbelt. Artikel ketiga, diajukan oleh Yayuk Hidayah, Sapriya , Cecep Darmawan, dan Elly Malihah tentang "Penggalangan Civic Literacy Melalui Organisasi Kemahasiswaan dan Pandangan mengenai Tantangan Demokrasi di Indonesia." Kajian tersebut merupakan analisis deskriptif tentang penggalangan civic literacy (literasi kewarganegaraan) di kalangan mahasiswa yang terlibat dalam organisasi kemahasiswaa terutama dengan menempatkan konteks momentum Pemilu 2019 untuk mengungkapkan pandangan para mahasiswa tentang tantangan demokrasi di Indonesia. Artikel keempat disusun oleh Zainal Arifin yang bertajuk "Kami Bali-Lampung: Politik Identitas Etnik Bali Migran dalam Masyarakat Multikultural Way Kanan, Lampung." Artikel ini menjelaskan bagaimana politik identitas etnik yang dipraktikkan komunitas Bali migran di wilayah Lampung yang multikultural, dimana upaya penyesuaian budaya (cultural conformity) dilakukan oleh komunitas etnik Bali Sadhar untuk menghindarkan konflik sosial dengan beragam etnis lainnya yang mendiami wilayah pemukiman transmigrasi di Lampung. Artikel kelima ditulis oleh Sinta Dwi Mustikawati yang berjudul "This is Not a Power Game: Dinamika Perkawinan Campur dalam Sebuah Relasi Bisnis." Artikel ini merupakan kajian tentang tatanan sosial yang membahas hubungan privat (romantis) di dalam perkawinan campuran antara perempuan Indonesia dengan pria asing (kulit putih / bule) dimana pertautan dan sengkarut kepentingan masyarakat moderen ikut berpengaruh. Menurutnya dinamika kuasa antara perempuan Indonesia dan laki-laki kulit putih dalam konteks pasangan perkawinan campur menjadi kompleks dalam relasi kontraktual terutama yang mengelola bisnis bersama. Relasi lintas bangsa, terutama relasi antarras di Indonesia masih dibayangi oleh stereotipe mobilitas vertikal. Artikel keenam diajukan oleh Nurindah Sari, Kaharuddin , Zainudin Hassan tentang "Komite Sekolah dan Pengembangan Pendidikan: Studi Kasus SMA Makassar." Artikel ini mendeskripsikan bentuk kontribusi komite sekolah dalam pengembangan pendidikan di sekolah menengah atas dengan menggunakan studi kasus sehingga dapat mengidentifikasi faktor-faktor apa saja yang menjadi daya dukung atau bahkan penghambat pengembangan pendidikan sebagai dampak dari pelembagaan Komite Sekolah di sekolah menengah atas. Demikian pilihan sajian artikel-artikel tersebut untuk penerbitan Jurnal Pemikiran Sosiologi Volume 7 No.1 Tahun 2020 kali ini semoga bermanfaat di dalam upaya (ikhtiar) untuk menelisik konsep, lembaga dan pengorganisasian tatanan sosial di Indonesia.

Salam,

Dewan Redaksi Jurnal Pemikiran Sosiologi. 